\title{
The Effectiveness of Rational Emotive Behavior Therapy Approach Using a Group Setting to Overcome Anxiety of Students Facing Examinations
}

\author{
Misdeni $^{1}$, Syahniar ${ }^{1}$, Marjohan ${ }^{1}$ \\ ${ }^{1}$ Universitas Negeri Padang \\ *Corresponding author, e-mail: misdenijhon@gmail.com
}

\begin{abstract}
The purpose of this study was to examine the effectiveness of the Rational Emotive Behaviour Therapy approach using a group setting in overcoming the anxiety of students facing examinations. This type of research is quantitative using an experimental approach. The research subjects were 10 students of the class VIII.2, with either high, moderate or low levels of anxiety. The instrument used was an Anxiety Questionnaire using a Likert model scale. Data analysis used descriptive statistics of the Wilcoxon Signed Rank test. The results of the study show that the group activities using the REBT approach affected the anxiety scores of students facing exams. This conclusion was measured in 3 ways. Specifically: (1) Describe the form of students'anxiety in facing the test before treatment (pretest); (2) Describe the form of students' anxiety in facing the exam after treatment (post-test); and (3) Test the effectiveness of the Rational Emotive Behaviour Therapy approach using a group setting to overcome students' anxiety in facing examinations in junior high school.
\end{abstract}

Keywords: Effectiveness of the REBT Approach, Anxiety, Student Exam

How to Cite: Misdeni, M., Syahniar, S., \& Marjohan, M. (2019). The Effectiveness of Rational Emotive Behavior Therapy Approach Using a Group Setting to Overcome Anxiety of Students Facing Examinations. International Journal of Research in Counseling and Education 3(2), 82-88, https://doi.org/10.24036/0064za0002

\section{Introduction}

Suryabrata (1986) suggests that when anxiety arises, it will encourage people to make an effort to reduce their anxiety or to prevent dangerous impulses. One example is that students who are anxious about examinations will do their best to study harder.

Gregory (in Rahmiwati, 2016)suggests anxiety facing exams is a phenomenological, physiological, and behavioural response that accompanies concerns about the possibility of failure in an exam. Each individual experiences anxiety at different levels, from the invisible to excessive fear which can be crippling.

Official research byAgustiar and Asmi (2010) explains that the fear of failing an exam is considered to have a positive value. However, anxiety with high intensity and a negative nature can cause harm and interfere with the physical and psychological state of the individual concerned. Eysenck, M.W., Santos, R., and Derakshan (2007) states that individuals who are in an anxious state will try to develop effective strategies to relieve these anxieties in order to achieve success. If an individual is too anxious before the exam it will interfere with their clarity of mind, desire to learn, self-resilience and memory for effective learning.

Yusuf (2005) suggests that tests can be grouped into: (1) formative tests, namely tests given to monitor learning progress during the education/learning process; (2) summative tests, namely tests given with the intention of knowing the mastery/achievement of students in certain fields, which will determine the value. These tests are often carried out in the middle/end of the semester; (3) placement tests, which are given in order to determine the direction a student/group will enter; and (4) diagnostic tests, namely tests used to diagnose the causes of difficulties faced by a person, including those which affect a person intellectually, emotionally, physically and any other difficulties that interfere with their learning activities. 
Students think examinations are a determinant of learning success. Students also think it is difficult to understand exam questions, are unable to answer exam questions, think that some material is not well understood even though they have been taught by the teacher, and are afraid of not passing the exam. Such thoughts make students feel less comfortable, experience conflict, low confidence, and think irrationally.

Anxiety can be influenced by several aspects, including the aspects of mood and cognition (Semiun, 2006). Mood includes feeling afraid of something that will be considered threatening, and cognitive aspects are influenced by thoughts and plans to avoid something threatening. Based on this, the perceived anxiety will lead to a threatening feeling and the individual will try to think of avoiding the threat. This avoidance behaviour will appear to give a comfortable feeling. Comfortable feeling is a form of mood that comes from thinking, called cognitive, and manifests through behaviour thus it can be interpreted that anxiety is influenced by someone's cognitive-behaviour.

Sundari (2005) suggests anxiety occurs due to 3 reasons: (1) Individuals are not able to make adjustments to themselves in the environment in general; (2) manifestations of mixed frustration and conflict of excessive guilt feelings; and (3) the cause of anxiety is out of awareness and unclear, such as excessive fear with no known cause.

Guidance and counselling (BK) are an integral part of the overall implementation of the education unit curriculum. Guidance and counselling have techniques and approaches to overcome anxiety. Mappiare (2011) explains the purpose of Rational Emotive Behaviour Therapy, namely "eliminating anxiety, fear, worry, and self-confidence". Regarding anxiety experienced based on cognitive and mood aspects, Rational Emotive Behaviour Therapy (REBT) is an approach that focuses on cognitive-behaviour. One of the counselling approaches that can be used by school counsellors is the REBT approach. Ellis, A., and Dryden (2003) explain the REBT approach in counselling as follows:

"Rational Emotive Behaviour Therapy is an approach to counselling that can be placed firmly in the cognitive-behavioural tradition of psychotherapy, meaning that it particularly focuses on the way that we think and behave, in its attempt to understand our emotional responses".

The implementation of REBT in helping to overcome anxiety can be through group format.The group activities in Rational Emotive Behaviour Therapy also have a purpose, which is explained inEllis (in Gerald, 2012) as follows:

"Two of the main goals of Rational Emotive Behaviour Therapy are to assist clients in the process of achieving unconditional self-acceptance (USA) and unconditional other acceptance (UOA), and to see how these are interrelated. To the degree that group members are able to accept themselves, they are able to accept others".

Rahmiwati (2016) found that counselling rational emotive behaviour was able to reduce the anxiety of 150 Middle School students in Jakarta facing tests on physical and motivational aspects. The results showed that there were differences in anxiety levels of students who were given REBT group counselling compared to students who were given regular group counselling. The decrease in the average score of anxiety in the control group was 142.25, while in the treatment group it was 142.

Various studies conducted by experts in America have proven that REBT is effective in helping to overcome individual problems.Banks and Zionts (in Bardujaman, 2007) noted several experts who proved that REBT counselling was effective, such as Ellis, Wilde, Knaus, La Conte, Show and Dunn, Snap and Farrel, Vemon, and Zionts. Albert Ellis was the initiator of the approach, and showed success in overcoming the problems experienced by clients. Ellis, 2005 (in Nelson, 2006) suggests that during group counselling with the REBT approach members are taught to detect each other and refute irrational beliefs.

Based on the results of researchers interviewing several BK teachers, there were several students who came for counselling who experienced anxiety about taking school examinations. One of the counsellors revealed that every day there were students who came for counselling with anxious complaints about school exams, including students of classes VII, VIII and IX. Many of the prominent factors of anxiety shown by these students are the target values which are too high, the value of anxiety in the previous semester is low, students have a lack of confidence in their abilities, and a fear that they did not gain a satisfactory grade. Most of the students who came for counselling were grade IX students, due to experiencing anxiety about the national exam which was near the time of implementation. However, there are also many students from grades VII and VIII who experience anxiety complaints similar to the semester exams.

The anxiety of these students is mostly caused by their learning time in the second semester as it is too short, the feeling of fear or worry that does not pass so they get a low score, and the feeling that the subject matter is still not well understood. Anxiety can also be caused by intense study time outside of school hours, 
sports and extracurricular activities. Anxiety with a reasonable intensity can be considered to have a positive value. However, anxiety with high intensity and a negative nature can cause harm and interfere with the physical and psychological state of the individual concerned. An individual being too anxious will interfere with their clarity of mind, desire to learn, self-resilience and memory to learn effectively.

Based on the description above, researchers are interested in examining the effectiveness of the Rational Emotive Behaviour Therapy approach using a group setting to overcome the anxiety of students facing exams. The purpose of this study is to: (1) Describe the form of students'anxiety in facing the test before treatment (pre-test); (2) Describe the form of students' anxiety in facing the test after treatment (post-test); and (3) Describe the effectiveness of the Rational Emotive Behaviour Therapy approach using a group setting to overcome students' anxiety in facing examinations.

\section{Method}

Yusuf (2013) this type of research is a quantitative pre-experimental study. The method of this research was carried out to obtain significant group differences if they are present. The experimental design used was the one group pre-post test. This design consists of one experimental group, with no control group. The design of this study was measured using a pre-test conducted before being given treatment, giving treatment, and post-test given after treatment.

Ten students were in the experimental group and all participants were subjected to the pre- and posttests and the group REBT. The instrument used for the research is the Anxiety Questionnaire, which used a Likert scale model. The data analysis technique uses nonparametric statistics with the Wilcoxon Signed Rank Test. Data analysis was assisted by using the SPSS version 20.00 program.

\section{Results and Discussion}

\section{Data Description}

Data in this study include: (1) Describe the form of students'anxiety facing examinations before treatment (pre-test);(2) Describethe form of students' anxiety in facing the exam after treatment (posttest);and (3) Describing the effectiveness of the Rational Emotive Behaviour Therapy approach using a group setting to overcome students' anxiety in facing examinations at SMP Negeri 1 Lubuk Alung.

1. The anxiety condition of students facing examinations in SMP Negeri 1 Lubuk Alung before treatment (pre-test).

It can be seen that the average students'anxiety score before REBT group activities for the experimental group is 138, which is in the medium category. Based on the results of the pretest group,Rational Emotive Behaviour Therapy activities obtained an overview of the condition of students' anxiety towards the exam in the experimental group.Of the 10 students in the experimental group, 3 students had low anxiety, 4 students had moderate anxiety, and 3 had high anxiety. Variations in students' anxiety scores regarding facing examsaims to create group dynamics in the activities of the REBT so that each group can exchange ideas and opinions about the anxiety facing the test.

2. The anxiety condition of students facing examinations in SMP Negeri 1 Lubuk Alung after treatment (post-test).

There was a decrease in anxiety for students faced with the examafter being given group activities using the REBT approach. Previously, of the 10 students in the experimental group, 3 had low anxiety, 4 had moderate anxiety, and 3 had high anxiety. After being given group activities using the REBT approach, all 10 group members had very low category anxiety scores. Group members already understood and knew that anxiety from facing exams can be harmful to themselves.

\section{Differences in the pre-test and post-test experimental group}

Differences in the results of the pretestand posttest werealso seen from the results of the mean,standard deviation, maximum value, and minimum value. In the Table, it is shown that the means of anxiety scoresat posttest is much lower than the anxiety scores atpretest,with an average difference of 20. Further details of this difference can be seen in Figure 1, below. 


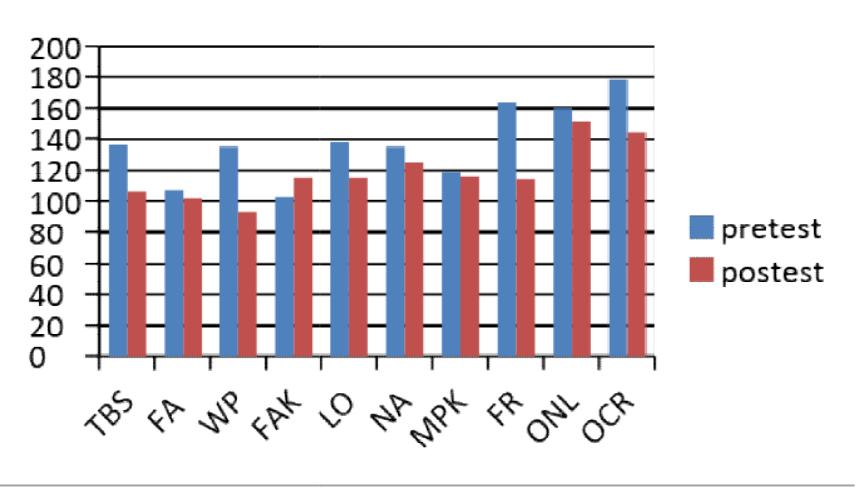

Figure1: Differences between pretest and posttestGroup Experiments on Anxiety of 10 Students Facing Trials

Based on Figure 1, there are clearly visible differences between students facing exam anxietybefore being given treatment in the form of group activities using the REBT approach,and students after being given treatment in the form of group activities using the REBT approach. The diagram shows a decrease in the score of postteststudents' anxiety facing the test.

\section{The Testing Data Analysis Requirements}

Test requirements for the analysis carried out in this research data are the Wilcoxon test.

\section{Wilcoxon Signed Ranks Test}

Hypothesis testing will be analysed through nonparametric statistics by Wilcoxon's test, and the calculation was conducted using the help of SPSS for Windows Release 20.00.

Table 1: Results of Wilcoxon Signed Ranks Pretest -Posttest and Analysis of Students ' Anxiety in Facing Exams.

\section{Test Statistics}

\begin{tabular}{|l|r|}
\hline & postest - pretest \\
\hline$Z$ & $-2,293^{\mathrm{b}}$ \\
Asymp. Sig. (2-tailed) &, 022 \\
\hline
\end{tabular}

a. Wilcoxon Signed Ranks Test

b. Based on positive ranks.

Based on the data in Table 1, it can be seen that students' anxiety when facing an exam is significantly lowerafter the group REBT (Asymp. Sig. (2-tailed)0.022,p=<0.05). Therefore, from these results, it is known that there are significant differences in students' anxiety when being faced with a test before and after REBT group treatment.

\section{Discussion}

1. Description of students' anxiety facing examinations in SMP Negeri 1 Lubuk Alung before treatment (pre-test)

An overview of the anxiety of the 10 experimental students facing school examinations is obtained through the results of the pretest, which was an average of 138 , which is in the medium category.Based on these resultsit can be interpreted that students have moderate anxiety about completing school exams. The pretestdata shows that anxiety symptoms most often experienced by the group members was that the heart beats very fast, resulting in impaired concentration and a decrease in the value of student learning outcomes due to taking the test in the anxious state. This is an anxiety symptom triggered by individual thinking.Eysenck, M.W., Santos, R., and Derakshan (2007) states that 
individuals who are in an anxious state will try to develop effective strategies to relieve these anxieties in order to achieve success. An individual being too anxious before the exam will actually interfere with their clarity of mind, desire to learn, self-resilience and memory for effective learning (Ardi et al., 2019).

Suhendri (2012) found several factors that triggered anxiety in students at school, including: (1) curriculum factors; (2) teacher factors; (3) school management factors; (4) future factors; and (5) competition factors.

Furthermore, the process of implementing the group REBT activities revealed various causes of students having anxiety facing exams. The more dominant factor that is experienced by group members is from the mood of worrying about low grades, worry about difficulty understanding the exam material, anxiety at the exam (Daharnis et al., 2018), feeling depressed when facing a difficult test, and worrying about exam material that has not been studied before. As for the somatic factors, students sometimes feel their heart pounding when the exam is finished, excessive sweating, and often feeling the need to urinate during the exam. Another factor that causes students to experience anxiety about examinations is the demand of parents to get good grades. The results of the study revealed that the factors that cause students to experience anxiety facing exams are both cognitive and biological. These factors are feeling disorders characterised by feelings of worry, fear, heart palpitations, and excessive sweating. Fear is one of the basic characteristics and functions of Id, because fear is an emotion associated with the survival of an individual, whether physical or psychological/cognitive. The fear in this situation serves to prepare individuals to run away from a threat that comes to them. Irrational thoughts such as those revealed have been rationalised with group activities using the REBT approach.

\section{Descriptions of anxiety students face examinations in SMP Negeri 1 Lubuk Alung after treatment (post-test)}

An overview of students' overall anxiety through post-testresults shows a decrease in anxiety scores of students facing exams in the experimental group after being provided with group activities using the REBT approach. This decrease is shown in that the average anxiety score can be categorised as 'low' after receiving group REBT, compared to an average 'moderate' score prior to group REBT. The overall average shows a decline in anxiety scores from 138 to 118, with an average difference in the decline of 20.The total score decline for the 10 students in the experimental group between pretest and posttestis 194. Decreasing students' anxiety scores by 20 is quite meaningful, as the addition of group REBT shows lower anxiety for taking examinations.

Sudrajat (in Agustiar \& Asmi, 2010) suggests that psychologically, stress can cause anxiety. Anxiety is one form of individual emotions that are related to the feeling of being threatened by something, usually with a less obvious threat object. Anxiety with reasonable intensity can be considered to have a positive value as it can lead to motivation to decrease anxiety with positive actions, but if the intensity is high and negative it can cause harm and disrupt the physical and psychological state of the individual concerned.

Students' readiness to face exams can also help to overcome anxiety facing exams. If students have a test preparation that is not mature, then students will potentially experience stress, which is called academic stress. Readiness here can be in the form of physical or mental readiness, test material, and readiness of exam equipment (Mandar, S., Syahniar., \& Syukur, 2017). In addition, self-confidence is also the first and most decisive factor in the success of students in school. Self-efficacy of students who are high in facing the exam faced, able to motivate students to face school exams. This is based on the results of Anggara's research, suggesting that peers who have high self-efficacy in the group are able to have positive effects on others so that they have increased self-confidence and become better (Anggara, F., Yusuf, A.M.,\& Marjohan, 2016).

Santrok (in Tulus, 2000) also explained that some students who succeeded in examinations were students who had moderate levels of anxiety. While students who have a high level of anxiety were associated with the lower test scores obtained. This shows that the students actually mastered the material being tested, but failed to show their true abilities due to the anxiety that hit them when facing the test.

After being given counselling services with the REBT approach students' anxiety begins to decline. This is because students already know the causes or characteristics of anxiety itself, the effects of anxiety, and how to overcome anxiety itself. Apart from a number of topics discussed in the group sessions, group leaders also added material about how to test success tips. Based on the observations of researchers from the beginning to the end of the implementation of counselling with the REBT approach, students who were not active in group activities at the beginning gradually began to actively discuss the topic of anxiety facing exams. Students also feel great benefits for the implementation of group counselling activities with the REBT approach to overcome their anxieties during the exam. 
3. The effectiveness of the Rational Emotive Behaviour Therapy approach using a group setting to overcome anxiety facing examinations in SMP Negeri 1 Lubuk Alung

The process of implementing group activities using the REBT approach is done with the model ABCDEof cognitive, emotive, and behavioural techniques on the REBT approach. Each meeting was conducted in three sessions, so the process of group activities carried out was varied and not monotonous. The theory of $A B C D E$ in the REBT approach is as follows:in the first step, students are asked to convey irrational thoughts about anxiety facing an exam(antecedent event/A); the group leaders then ask about their beliefs, and their beliefs about anxiety(Belief/B); group members will then display Emotional Consequence (C) (which are the are emotional consequences of the topics discussed); the group leader will then conduct a conflict of irrational thoughts of thestudentswith three counselling techniques of REBT (Dispute/D) Usually these are cognitive techniques with active solutions for irrational beliefs,emotive techniques with rational emotive imagery,and behavioural techniques by using a homework assignment.The three techniques are given at the group activity stage, so that the topic discussion is conducted in a structured manner.

The purpose of the counsellor is to provide the topic of the task with the aim that"members participate actively and dynamically in the discussion, both concerning the elements of behaviour, thought or feeling"(Prayitno, 1995: 53). REBT focus discusses the process of thought, feelings and behaviour (Ellis, A., \& Dryden, 2003), and within the group members share information and exchange ideas, experiences, and opinions. This means the members are mutually helpful, mutually accepting, mutually strong-reinforcing, and trying to strengthen each other's sense of togetherness (Prayitno, 1995).

\section{Conclusion}

Based on the results of the research data, it can be concluded that in general group sessions using the REBT approach effectively changes the anxiety scores for students facing exams. A Wilcoxon Signed Rank test showed that decreases in anxiety for students facing exams wassignificantly lower in post-test (Asymp. Sig. (2-tailed) $0.022, \mathrm{p}=<0.05$ ). In particular, there are differences in the average score of anxiety for students facing exams in the experimental group before and after participating in group activities using the REBT approach, where the average score after treatment is significantly lower than before the treatment (a change from moderate anxiety to low anxiety).

\section{References}

Agustiar, W., \& Asmi, Y. (2010). Kecemasan Menghadapi Ujian Nasional Dan Motivasi Belajar Pada Siswa Kelas Xii Sma Negeri "X" Jakarta Selatan. Jakarta Selatan Jurnal Psikologi, 8(1).

Anggara, F., Yusuf, A.M., \& M. (2016). Efektifitas Layanan Bimbingan Kelompok dengan Modeling dalam Meningkatkan Efikasi Diri Siswa dalam Menghadapi Ujian. Ejournal.Unp.Ac.Id/Index.Php/Konselor, 5(1), $42-49$.

Ardi, Z., Rangka, I. B., Ifdil, I., Suranata, K., Azhar, Z., Daharnis, D., ... Alizamar, A. (2019). Exploring the elementary students learning difficulties risks on mathematics based on students mathematic anxiety, mathematics self-efficacy and value beliefs using rasch measurement. In Journal of Physics: Conference Series (Vol. 1157, p. 32095). IOP Publishing.

Bardujaman. (2007). Penggunaan Pendekatan Rational Emotive Behavior Therapy pada setting Sekolah Indonesia. Bimbingan Konseling FIP UNJ.

Daharnis, D., Ardi, Z., Alizamar, A., Ifdil, I., Rangka, I. B., \& Suranata, K. (2018). Adaptation and validation of mathematics anxiety: Rasch and network psychometrics analysis. In Journal of Physics: Conference Series (Vol. 1114, p. 12113). IOP Publishing.

Ellis, A., \& Dryden, W. (2003). Albert Ellis Live. London $\square$ : Sage Publications.

Eysenck, M.W., Santos, R., \& Derakshan, N. (2007). Anxiety and Cognitive Performance Attentional Control Theory. American Psychological Assosiation, 72), 336.

Gerald, C. (2012). Theory and Practice of Group Counselling. Canada: Cengage Learning.

Mandar, S., Syahniar., \& Syukur, Y. (2017). Kesiapan Siswa yang Ditinggalkan Orangtua dalam Menghadapi Ujian. Ejournal.Unp.Ac.Id/Index.Php/Konselor, G(1), 24-28.

Mappiare, A. (2011). Pengantar Konseling dan Psikoterapi. (R. Pers, Ed.). Jakarta. 
Nelson, R. J. (2006). Teori dan Praktek: Konseling dan Terapi. (S. Prajitno, Helly; Mulyantini, Ed.). Jakarta. Prayitno. (1995). Layanan Bimbingan dan Konseling Kelompok. Jakarta: Ghalia Indonesia.

Rahmiwati, M. (2016). Keefektifan Konseling Rational Emotive Behavior (REB) Untuk Mengatasi Kecemasan Menghadapi Ujian Siswa di SMP N 150 Jakarta. Jurnal Prosiding UHAMKA.

Semiun, Y. (2006). Kesehatan Mental. Yogyakarta: Kanisius.

Suhendri. (2012). Pentingnya Konseling REBT untuk Mengentaskan Kecemasan Siswa Menghadapi Ujian. Jurnal Universitas Negeri Semarang.

Sundari, S. (2005). Kesehatan Mental dalam Kehidupan. Jakarta: Rineka Cipta.

Suryabrata, S. (1986). Psikologi Kepribadian. Jakarta: CV. Rajawali.

Tulus, W. (2000). Mempersiapkan Siswa Menghadapi Ujian Nasional. Jurnal Psikologi.

Yusuf, A. . (2005). Metode Penelitian Dasar-Dasar Penyelidikan IImiah. Padang: UNP Press.

Yusuf, A. . (2013). Metode Penelitian Kuantitatif, Kualitatif, dan Penelitian Gabungan. Padang: UNP Press. 